\title{
Pemanfaatan Citra VIIRS untuk Deteksi Asap Kebakaran Hutan dan Lahan di Indonesia
}

\section{Utilization of VIIRS Image for Detection of Forest and Land Fire in Indonesia}

Any Zubaidah, Sayidah Sulma, Suwarsono, Indah Prasasti

Pusat Pemanfaatan Penginderaan Jauh, Lembaga Penerbangan dan Antariksa Nasional (LAPAN) Jl. KALISARI No. 8, Pekayon, Pasar Rebo, Jakarta Timur, 13710, Indonesia

\section{Article Info:}

Received: 04 - 06 - 2018

Accepted: 24 - 05 - 2019

Keywords:

VIIRS image, composite, detection, forest and land fire, smoke haze.

\section{Corresponding Author:}

Any Zubaidah

Pusat Pemanfaatan Penginderaan Jauh, Lembaga Penerbangan dan Antariksa Nasional (LAPAN); Tel. +62-21-8710065

Email:

any.zubaidah@lapan.go.id/atau baidah_any@yahoo.com

\begin{abstract}
The observation of smoke because of land and forest fires in some regions in Indonesia mostly use the composite image visually. This study aims to develop the detection model of forest and land fire smoke using a digital analysis, which will be faster in supporting spatial information on emergency response in monitoring forest and land fire smoke. The method used is multithreshold method and compare it with the existing model that is by modification of method Li et al. (2015). The data used is Suomi NPP-VIIRS satellite imagery. The results concluded that the VIIRS image can be used to detect the smoke and smoke distribution of forest fire and digital smoke. The multi-threshold model uses reflectance data obtained from the M4 visible channel, and the brightness temperature data obtained from the LWIR VIIRS M14 channel, with an average accuracy of $82.2 \%$ with a Commision error of $9.8 \%$ and an Ommision error of $10 \%$. While the model of modification Li is based only on reflectance of visible-channel data i.e. channel M1, M2, M3, and SWIR VIIRS M11 channel, which has an average accuracy of $72.3 \%$ with a Commision error of $0.3 \%$ and an Ommision error of $27.4 \%$. The multithreshold model is a model that has the potential to be applied to detect forest and land fire smoke.
\end{abstract}

How to cite (CSE Style $8^{\text {th }}$ Edition):

Zubaidah A, Sulma S, Suwarsono, Prasasti I. Pemanfaatan citra VIIRS untuk deteksi asap kebakaran hutan dan lahan di Indonesia. JPSL 9(4): 929-945. http://dx.doi.org/10.29244/jps1.9.4. 929-945.

\section{PENDAHULUAN}

Salah satu dampak kebakaran hutan/lahan yang sangat merugikan adalah gangguan kabut asap. Kabut asap, selain menyebabkan gangguan pada kesehatan manusia akibat subtansi yang beracun (Tie et al. 2009), penerbangan, juga sebarannya dapat mengganggu hubungan antar negara terutama jika melintasi batas negara (Tacconi 2003). Oleh karena itu, pemantauan jelajah sebaran kabut asap tersebut penting dilakukan dengan memanfaatkan teknologi penginderaan jauh, seperti VIIRS.

LAPAN dalam penyediaan informasi tanggap darurat bencana kebakaran hutan dan lahan telah menggunakan citra komposit RGB dari data AVHRR (NOAA), MODIS (Terra dan Aqua), Landsat 8 OLI dan SPOT 6 untuk pemantauan sebaran kabut asap. Zubaidah et al. (2014) dan Priyatna et al. (2014) telah menggunakan citra komposit MODIS secara visual untuk pengamatan kabut asap di beberapa wilayah di Indonesia. Citra komposit ini dapat digunakan untuk membedakan secara visual asap dari tutupan lainnya seperti vegetasi, awan dan air. Namun, pendekatan ini hanya dapat memberikan informasi dasar tentang asap, tetapi tidak dapat digunakan dalam prosedur deteksi asap secara otomatis. Oleh karena itu, penelitian ini 
mencoba mengenali karakteristik spektral kabut asap guna membangun model deteksi dan/atau identifikasi kabut asap dari data VIIRS.

Beberapa penelitian terdahulu telah mengaplikasikan citra penginderaan jauh untuk mendeteksi asap kebakaran hutan/lahan. Pendekatan yang paling sering digunakan adalah dengan membuat citra komposit RGB true atau false color composit. Chung dan Le (1984) mendeteksi kabut asap kebakaran yang terjadi di hutan Canada menggunakan citra komposit false color RGB kombinasi kanal 1, 2 dan 4 dari citra AVHRR. Chung dan Kim (2008) juga menggunakan teknik yang sama yang dilakukan oleh Chung dan Le (1984) namun lokasinya di Korea Utara dan Korea Selatan. Identifikasi kabut asap dapat dilakukan menggunakan citra komposit MODIS RGB true color gabungan kanal 1, 4 dan 3.

Dalam perkembangan selanjutnya, upaya pengembangan metode deteksi asap secara otomatis yang akurat juga dilakukan antara lain melalui pendekatan multi-threshold yang didasarkan pada perbedaan sifat fisik antara asap dan tipe tutupan lainnya seperti vegetasi, awan dan air. Secara umum metode ini menggunakan ambang batas untuk mengecek semua piksel secara otomatis untuk memisahkan piksel nonasap setahap demi setahap (Li et al. 2015). Deteksi asap secara otomatis atau digital juga dilakukan oleh Baum dan Trepte (1999) yang membangun metode kelompok threshold dari nilai reflektansi dan brightness temperature (BT) dari citra AVHRR untuk identifikasi dan memisahkan objek awan, api, asap dan salju di wilayah Amerika Tengah. Metode ini menerapkan kelompok threshold secara bersamaan untuk mengkelaskan masing-masing piksel, atau tidak secara berurutan. Masih menggunakan data AVHRR, Li et al. (2001) mengembangkan metode deteksi asap dengan menggabungkan antara metode Artificial Neural Network dan teknik multi-threshold. Kedua metode ini dapat diterapkan secara bersamaan atau terpisah tergantung pada ukuran asap dan citra. Selanjutnya, algoritma yang diperoleh dibandingkan dengan data Hotspot dan data indeks aerosol TOMS. Xie et al. (2007) mengembangkan metode multi-threshold menggunakan 8 kanal citra MODIS untuk membedakan kabut asap dengan tutupan lahan lainnya seperti asap, vegetasi dan salju di wilayah timur Amerika. Sejumlah ujicoba dilakukan dalam penelitian tersebut untuk memisahkan piksel non-asap secara bertahap, kemudian algoritma multi-threshold divalidasi menggunakan citra komposit true color. Zhao et al. (2010) melakukan deteksi debu dan asap kebakaran berdasarkan ujicoba nilai threshold spektral dan spasial bersama dengan beberapa tekstur keseragaman dari reflektansi dan $B T$ citra MODIS. Algoritma yang dibangun memungkinkan untuk deteksi asap tebal, baik yang ada di atas permukaan darat maupun air. Namun demikian, algoritma ini masih memiliki kekurangan, yakni kurang baik digunakan untuk deteksi asap tipis karena sinyal aerosol yang relatif lemah. Algoritma ini dapat pula diaplikasikan pada citra multi kanal lainnya, seperti EOS, VIIRS dan GOES-R. Sementara Li et al. (2015) membangun algoritma yang lebih fleksibel dan otomatis untuk identifikasi asap menggunakan data MODIS berdasarkan metode back-propagation neural network (BPNN).

Berakhirnya masa operasi MODIS dan munculnya satelit generasi baru yang membawa sensor VIIRS menjadikan tantangan dalam upaya memanfaatkan kanal-kanal yang dimilikinya. Oleh karena itu, penelitian ini ditujukan untuk menggali potensi pemanfaatan kanal-kanal VIIRS guna mengembangkan algoritma deteksi sebaran asap kebakaran hutan/lahan. Hal ini dilakukan guna mengantisipasi berakhirnya masa pengoperasian data MODIS.

VIIRS merupakan kependekan dari Visible and Infrared Imaging Radiometer Suite. VIIRS merupakan salah satu sensor yang dibawa oleh satelit Suomi-NPP (National Polar - orbiting Operational Environmental Satellite System Preparatory Project) yang diluncurkan pada tanggal 28 Oktober 2011. Sensor VIIRS terdiri atas enam belas kanal resolusi moderate (M-Bands) mulai dari $\mathrm{M}_{1}$ hingga $\mathrm{M}_{16}$, satu kanal Band Day/Night (DNB), dan lima kanal imagery resolusi tinggi (I-Bands) yaitu II hingga I5. Menurut Seaman (2013) dan Lee et al. (2006), data VIIRS merupakan kelanjutan dari tiga instrumen satelit, yakni: National Oceanic and Atmospheric Administration (NOAA) Advanced Very High Resolution Radiometer (AVHRR), Moderate Resolution Imaging Spectroradiometer (MODIS), dan Defense Meteorological Satellite Program (DMSP) Operational Linescan System (OLS). 
Sensor VIIRS dapat digunakan untuk berbagai macam aplikasi pemantauan secara global di wilayah daratan, lautan, dan parameter atmosfer lainnya, seperti badai topan, deteksi kebakaran hutan/lahan, asap, dan aerosol atmosfer. Sensor VIIRS memiliki kesamaan dengan satelit-satelit sebelumnya, seperti: AVHRR, OLS, MODIS, SeaWiFS. Sensor VIIRS terdiri dari 22 kanal dengan liputan kanal spektral sebesar $412 \mathrm{~nm}$ hingga $12 \mu \mathrm{m}$, kanal imagery dengan resolusi nadir sekitar $\sim 375$ meter dalam lima kanal, yakni Imagery 1 hingga Imagery 5. Luas liputan satu citra sebesar $3000 \mathrm{~km}$, dengan resolusi spasial: 370/740 m. Informasi mengenai karakteristik teknis dari sensor VIIRS yang terdiri dari bandwidth, band explanation, spatial resolution, hingga pemanfaatan yang paling utama daripada data VIIRS ditunjukkan pada Tabel 1.

Tabel 1. Informasi mengenai karakteristik teknis masing-masing kanal dari sensor VIIRS, Sumber NOAA.

\begin{tabular}{|c|c|c|c|c|c|c|c|c|}
\hline No. & $\begin{array}{l}\text { VIIRS } \\
\text { Band }\end{array}$ & $\begin{array}{l}\text { Central VIIRS } \\
\text { Wavelength } \\
\text { (um) }\end{array}$ & $\begin{array}{l}\text { Bandwidth } \\
(\mu \mathrm{m})\end{array}$ & $\begin{array}{c}\text { Wavelength } \\
\text { Range } \\
\text { (um) }\end{array}$ & $\begin{array}{c}\text { Band } \\
\text { Explanation }\end{array}$ & $\begin{array}{c}\text { Spatial } \\
\text { Resolution } \\
\text { (m)@ Nadir }\end{array}$ & $\begin{array}{l}\text { Band } \\
\text { Gain }\end{array}$ & $\begin{array}{c}\text { Primary } \\
\text { Application }\end{array}$ \\
\hline 1. & $\mathrm{Ml}$ & 0.412 & 0.02 & $0.402-0.422$ & \multirow{5}{*}{$\begin{array}{l}\text { Visible/ } \\
\text { Reflective }\end{array}$} & \multirow{16}{*}{$750 \mathrm{~m}$} & $\begin{array}{l}\text { High } \\
\text { low }\end{array}$ & $\begin{array}{l}\text { Ocean color, } \\
\text { aerosols }\end{array}$ \\
\hline 2. & $\mathrm{M} 2$ & 0.445 & 0.018 & $0.436-0.454$ & & & $\begin{array}{l}\text { High } \\
\text { low }\end{array}$ & $\begin{array}{c}\text { Ocean color, } \\
\text { aerosols }\end{array}$ \\
\hline 3. & MB & 0.488 & 0.02 & $0.478-0.488$ & & & $\begin{array}{l}\text { High } \\
\text { low }\end{array}$ & $\begin{array}{c}\text { Ocean color, } \\
\text { aerosols }\end{array}$ \\
\hline 4. & M4 & 0.555 & 0.02 & $0.545-0.565$ & & & $\begin{array}{l}\text { High } \\
\text { low }\end{array}$ & $\begin{array}{l}\text { Ocean color, } \\
\text { aerosols }\end{array}$ \\
\hline 5. & M5(B) & 0.672 & 0.02 & $0.662-0.682$ & & & $\begin{array}{l}\text { High } \\
\text { low }\end{array}$ & $\begin{array}{c}\text { Ocean color, } \\
\text { aerosols }\end{array}$ \\
\hline 6. & M6 & 0.746 & 0.015 & $0.739-0.754$ & \multirow{2}{*}{ Near IR } & & single & $\begin{array}{l}\text { Atmospheric } \\
\text { correction }\end{array}$ \\
\hline 7. & $\mathrm{M} 7(\mathrm{G})$ & 0.865 & 0.039 & $0.846-0.885$ & & & $\begin{array}{l}\text { High } \\
\text { low }\end{array}$ & $\begin{array}{l}\text { Ocean color, } \\
\text { Aerosols }\end{array}$ \\
\hline 8. & M8 & 1.24 & 0.020 & $1.23-1.25$ & \multirow{4}{*}{$\begin{array}{l}\text { Shortwave } \\
\text { IR }\end{array}$} & & single & $\begin{array}{c}\text { Cloud particle } \\
\text { size }\end{array}$ \\
\hline 9. & $\mathrm{M} 9$ & 1.38 & 0.015 & $1.371-1.386$ & & & single & $\begin{array}{l}\text { Cimus cloud } \\
\text { cover }\end{array}$ \\
\hline 10. & $\mathrm{MlO}(\mathrm{R})$ & 1.61 & 0.06 & $1.58-1.64$ & & & single & Snow fraction \\
\hline 11. & $\mathrm{Mll}$ & 2.25 & 0.05 & $2.23-2.28$ & & & single & Clouds/aerosol \\
\hline 12. & $\mathrm{M} 12$ & 3.70 & 0.18 & $3.61-3.79$ & \multirow{2}{*}{$\begin{array}{l}\text { Medium- } \\
\text { wave IR }\end{array}$} & & single & $\begin{array}{l}\text { Sea surface } \\
\text { temperature } \\
\text { (SST) }\end{array}$ \\
\hline 13. & $\mathrm{Ml3}$ & 4.05 & 0.155 & $3.97-4.13$ & & & $\begin{array}{l}\text { High } \\
\text { low }\end{array}$ & $\begin{array}{l}\text { SST, fire } \\
\text { detection }\end{array}$ \\
\hline 14. & Ml4 & 8.55 & 0.3 & $8.4-8.7$ & \multirow{3}{*}{$\begin{array}{l}\text { Longwave } \\
\text { IR }\end{array}$} & & single & $\begin{array}{l}\text { Cloud-top } \\
\text { properties }\end{array}$ \\
\hline 15. & Ml5 & 10.76 & 1.0 & $10.26-11.26$ & & & single & SST \\
\hline 16. & M16 & 12.01 & 0.95 & $11.54-12.49$ & & & single & SST \\
\hline 17. & $\mathrm{DNB}$ & 0.7 & 0.4 & $0.5-0.9$ & $\begin{array}{c}\text { Visible } \\
\text { Reflective }\end{array}$ & $\begin{array}{c}750 \mathrm{~m} \text { across } \\
\text { full scan }\end{array}$ & single & Imagery \\
\hline 18. & $\begin{array}{c}\text { Imagingl/ } \\
\text { Il (B) }\end{array}$ & 0.640 & 0.08 & $0.6-0.68$ & $\begin{array}{l}\text { Visible } \\
\text { Reflective }\end{array}$ & \multirow{5}{*}{$375 \mathrm{~m}$} & single & $\begin{array}{c}\text { Visibel Imagery/ } \\
\text { NDVI }\end{array}$ \\
\hline 19. & $\begin{array}{c}\text { Imaging } 2 / \\
I 2(G)\end{array}$ & 0.865 & 0.039 & $0.85-0.88$ & Near IR & & single & $\begin{array}{c}\text { Land Imagery/ } \\
\text { NDVI }\end{array}$ \\
\hline 20. & $\begin{array}{c}\text { Imaging } 3 / \\
\text { I3 }(\mathrm{R})\end{array}$ & 1.61 & 0.06 & $1.58-1.64$ & $\begin{array}{c}\text { Shortwave } \\
\text { IR }\end{array}$ & & single & $\begin{array}{l}\text { Binary snow } \\
\text { ice, map }\end{array}$ \\
\hline 21. & $\underset{\text { I4 }}{\text { Imaging }}$ & 3.74 & 0.38 & $3.55-3.93$ & $\begin{array}{l}\text { Medium- } \\
\text { wave IR }\end{array}$ & & single & imagery cloud \\
\hline 22. & $\underset{\text { I } 5}{\text { Imaging } 5 /}$ & 11.45 & 1.9 & $10.5-12.4$ & $\begin{array}{c}\text { Longwave } \\
\text { IR }\end{array}$ & & single & imagery cloud \\
\hline
\end{tabular}

Sumber: NOAA (2014), Lee et al. (2006). 
Penelitian ini bertujuan untuk mengembangkan algoritma untuk mendeteksi asap kebakaran hutan/lahan dari data VIIRS. Algoritma ini dikembangkan berdasarkan metode multi-threshold. Sebagai pembanding, penelitian ini juga menggunakan algoritma Li et al. (2015) dan Zhao et al. (2010) yang dimodifikasi agar dapat diterapkan di wilayah Indonesia. Selanjutnya, deteksi asap kebakaran hutan/lahan didasarkan pada model yang terbaik yang diperoleh dalam penelitian ini. Walaupun, pada aplikasinya harus dievaluasi agar dapat dioperasionalkan.

\section{METODE}

\section{Data}

Data utama yang digunakan dalam penelitian ini adalah data VIIRS bulan Oktober 2015. Pemilihan data yang digunakan didasarkan pada adanya indikasi asap kebakaran hutan/lahan. Data VIIRS perekaman tanggal 4 Oktober 2015 digunakan dalam penentuan model deteksi asap kebakaran hutan/lahan, sedangkan data VIIRS lainnya tanggal 10, 11, dan 15 Oktober 2015 yang terindikasi asap digunakan dalam aplikasi modelnya.

Data VIIRS diperoleh dari Pusat Teknologi dan Data Penginderaan Jauh - LAPAN dalam format HDF h5. Data ini merupakan data level SDR (Sensor Data Record) yang didalamnya sudah tersimpan informasi geolocation dan data sudah terkonversi menjadi nilai radian, reflektansi, dan/atau suhu kecerahan (Brightness Temperature $=B T$ ). Kanal yang diolah meliputi data resolusi moderat $\mathrm{M}_{1}$ sampai dengan $\mathrm{M}_{16}$ yang disertakan dengan file geolocation GMTCO. Selain itu, digunakan pula data hotspot (MODIS, dan VIIRS) harian pada bulan Oktober 2015 sebagai informasi yang mendukung bahwa wilayah tersebut terindikasi terjadi kebakaran hutan/lahan. Prasasti et al. (2012), menyebutkan bahwa hotspot merupakan alat yang dapat dipercaya untuk deteksi kebakaran hutan dan lahan.

Peta batas Administrasi Provinsi wilayah Indonesia yang diperoleh dari Badan Informasi Geospasial digunakan untuk menentukan batas-batas administrasi Provinsi.

\section{Metode Pengolahan Data}

\section{Pengolahan awal citra}

Pengolahan awal meliputi koreksi geometrik menggunakan VIIRS Conversion Toolkit dengan mengambil informasi geolocation dari file GMTCO, sekaligus dapat diekstrak nilai reflektansi dan nilai $B T$ dari setiap kanal. Kanal $\mathbf{M}_{1}$ sampai dengan kanal $\mathbf{M}_{11}$ memuat nilai reflektansi, dan sedangkan kanal $\mathbf{M}_{12}$ sampai dengan kanal $\mathrm{M}_{16}$ memuat nilai $B T$.

Proses selanjutnya dilakukan pemotongan citra sesuai wilayah Indonesia (khususnya di Pulau Sumatera dan Kalimantan) dan dibuat citra komposit RGB 3-2-1 dan atau komposit RGB 10-7-2. Selanjutnya citra komposit tersebut digunakan dalam pengambilan training sampel atau area untuk masing-masing obyek (asap dan non asap) guna kepentingan klasifikasi obyek asap dan non asap. Selanjutnya, dari hasil klasifikasi masingmasing obyek asap dan non asap (awan, vegetasi, dan air) ditentukan pola reflektansi dan $B T$ masing-masing obyek tersebut.

\section{Pengembangan model deteksi asap kebakaran hutan dan lahan berdasarkan teknik multi-threshold}

Model deteksi asap kebakaran hutan/lahan dalam penelitian ini dilakukan dengan terlebih dulu menganalisis spektral obyek asap dan non asap. Analisis spektral obyek asap dan non asap ini dilakukan untuk memilih kanal yang tepat guna mengidentifikasi obyek asap dan membedakannya dengan obyek lain. Secara kuantitatif, untuk tujuan analisis kemampuan masing-masing kanal tersebut terhadap variasi antara dua obyek dapat dilakukan dengan menghitung nilai normalized distance (D). Nilai D dihitung dengan persamaan berikut (Kaufman and Remer, 1994; Li et al. 2014; Li et al. 2015): 


$$
D=\frac{\left|\mu_{1}-\mu_{2}\right|}{\left(\sigma_{1}+\sigma_{2}\right)}
$$

dengan $\mu_{1}$ dan $\mu_{2}$ adalah nilai rata-rata obyek 1 dan obyek 2 , sementara $\sigma_{1}$ dan $\sigma_{2}$ adalah standar deviasi dari obyek 1 dan obyek 2 . Semakin besar nilai D, maka perbedaan dari kedua obyek makin besar sehingga akan semakin mudah membedakan antara obyek 1 dan obyek 2 .

Selanjutnya, pengembangan algoritma deteksi asap kebakaran hutan/lahan berdasarkan teknik Multithreshold ini dilakukan berdasarkan nilai threshold reflektansi obyek dari kanal-kanal yang terpilih untuk mendeteksi asap. Kanal-kanal tersebut dipilih berdasarkan nilai D paling tinggi di antara kelas-kelas obyek. Secara statistik, nilai threshold dapat diukur dari nilai rata-rata $(\mu)$ dan deviasi standar $(\sigma)$ reflektansi obyek yang digunakan untuk deteksi asap. Berdasarkan asumsi distribusi normal, nilai threshold yang dipilih adalah $(\mu \pm 2 \sigma)$. Disamping itu, apabila terdapat kemiripan karakteristik reflektansi antara asap tipis dan awan tipis, maka perlu dilakukan pemisahan lebih lanjut menggunakan nilai $B T$ kanal inframerah thermal. Oleh karena itu, perhitungan nilai D guna penentuan nilai threshold dilakukan pula pada nilai $B T$ obyek asap dan obyek lainnya.

\section{Deteksi Asap dengan Modifikasi Model Li et al. (2015)}

Selain dengan teknik multi-threshold tersebut, penelitian ini juga membandingkan dengan model lain, yaitu dengan model Li et al. (2015) yang dimodifikasi. Maksud dimodifikasi disini adalah penyesuaian kanalkanal MODIS yang digunakan oleh Li et al. (2015) terhadap kanal-kanal pada VIIRS seperti dijelaskan dalam paragraf selanjutnya. Algoritma Li et al. (2015) merupakan hasil modifikasi dari model-model algoritma sebelumnya yang telah dikembangkan oleh Xie et al. (2007) dan Wang et al. (2007). Selanjutnya formulasi algoritma yang digunakan Li et al. (2015) adalah sebagai berikut:

$0.4 \leq\left(\mathrm{R}_{8}-\mathrm{R}_{19}\right) /\left(\mathrm{R}_{8}+\mathrm{R}_{19}\right) \leq 0.85$

$\left(\mathrm{R}_{9}-\mathrm{R}_{7}\right) /\left(\mathrm{R}_{9}+\mathrm{R}_{7}\right) \geq 0.3$

$\left(\mathrm{R}_{8}-\mathrm{R}_{3}\right) /\left(\mathrm{R}_{8}+\mathrm{R}_{3}\right) \leq 0.09$

$\mathrm{R}_{8} \geq 0.09$

dengan $\mathrm{R}_{\mathrm{i}}$ adalah reflektansi kanal ke-i untuk data MODIS.

Dalam penelitian ini, hasil modifikasi algoritma Li et al. (2015) dengan menggunakan data VIIRS formulasi algoritmanya menjadi:

$\left.\begin{array}{l}0.4 \leq\left(\mathrm{M}_{1}-\mathrm{M}_{7}\right) /\left(\mathrm{M}_{1}+\mathrm{M}_{7}\right) \leq 0.85 \\ \left(\mathrm{M}_{2}-\mathrm{M}_{11}\right) /\left(\mathrm{M}_{2}+\mathrm{M}_{11}\right) \geq 0.3 \\ \left(\mathrm{M}_{1}-\mathrm{M}_{3}\right) /\left(\mathrm{M}_{1}+\mathrm{M}_{3}\right) \leq 0.09 \\ \mathrm{M}_{1} \geq 0.09\end{array}\right\}$

dengan $M_{i}$ adalah reflektansi band ke-i untuk data VIIRS, sehingga kanal $R_{i}$ pada MODIS disesuaikan dengan kanal $\mathrm{M}_{\mathrm{i}}$ pada VIIRS.

\section{Uji Akurasi Model}

Akurasi model deteksi sebaran asap kebakaran hutan/lahan dari data VIIRS ini dilakukan dengan cara membandingkan hasil kedua model; model multi-threshold dan modifikasi model Li et al. (2015), dengan hasil delineasi obyek asap dan non asap berdasarkan interpretasi visual pada data tanggal yang sama. Sama seperti yang dilakukan oleh Zubaidah et al. (2017), penelitian ini juga menggunakan formula berikut ini untuk menguji akurasi model, yakni:

a) Overall Accuration $(\%)=\Sigma$ luas Corr/ $\Sigma$ luas $(\operatorname{Corr}+\operatorname{Comm}+$ Omm $) * 100$

b) Commission error $(\%)=\Sigma$ luas Comm/ $\mathrm{Cluas}(\mathrm{Corr}+\mathrm{Comm}+\mathrm{Omm}) * 100$

c) Omission error $(\%)=\Sigma$ luas $\mathrm{Omm} /$ Lluas $(\mathrm{Corr}+\mathrm{Comm}+\mathrm{Omm}) * 100$ 
dimana Corr $=$ Correction yaitu luas area asap kebakaran yang terdeteksi benar, Comm $=$ Commision error yaitu luas area asap kebakaran yang terdeteksi salah dikarenakan obyek non asap juga terdeteksi sebagai asap, sedangkan Omm = Ommision error adalah luas area asap kebakaran yang terdeteksi salah dikarenakan obyek asap terdeteksi sebagai non asap.

\section{HASIL DAN PEMBAHASAN}

\section{Pengolahan awal data}

Citra VIIRS yang digunakan dalam pengembangan model adalah citra tanggal 4 Oktober 2015. Selanjutnya pada citra ini dilakukan pengolahan awal. Citra VIIRS hasil pengolahan awal disimpan dalam file dengan format namafile.ers, yang dapat dibaca dalam berbagai perangkat lunak pengolahan. File tersebut terdiri 16 kanal ( $\mathrm{M}_{1}$ hingga kanal $\left.\mathrm{M}_{16}\right)$. Kanal $\mathrm{M}_{1}$ hingga $\mathrm{M}_{11}$ berisi nilai reflektansi, sedangkan pada kanal $\mathrm{M}_{12}$ hingga $\mathrm{M}_{16}$ berisi nilai-nilai $B T$.

Secara alami mata manusia hanya mampu mendeteksi gelombang elektromagnetik dengan panjang gelombang antara 0,4 sampai dengan $0,7 \mu \mathrm{m}$, yang dikenal sebagai sinar tampak. Pada selang panjang gelombang inilah konsep warna digunakan untuk mengasosiasikan obyek yang diamati oleh mata manusia. Panjang gelombang tampak terdiri dari tiga 3 warna dasar; merah (R), hijau (G), dan biru (B) (Planologi, 2013).

Citra komposit merupakan gabungan tiga kanal (R-G-B) yang mampu menampilkan keunggulan dari masing-masing kanal penyusunnya. Dengan demikian, keterbatasan mata yang kurang mampu dalam membedakan gradasi warna dapat lebih mudah dipahami perbedaan warnanya melalui citra komposit tersebut. Selanjutnya citra komposit ini digunakan untuk membedakan obyek asap dan non asap secara visual.

Gambar 1 merupakan citra komposit R-G-B kombinasi kanal 10-7-2 dari data VIIRS yang disebut sebagai true color komposit. Gambar 2 merupakan tampilan citra komposit warna lain, dengan tujuan untuk menonjolkan tampilan asap lebih jelas yaitu R-G-B kombinasi kanal 3-2-1. Citra tersebut di-overlay (tumpang susun) dengan data hotspot dari data VIIRS pada tanggal yang sama 4 Oktober 2015 (titik warna merah), untuk memastikan bahwa asap berasal dari kebakaran yang diindikasikan oleh adanya hotspot.

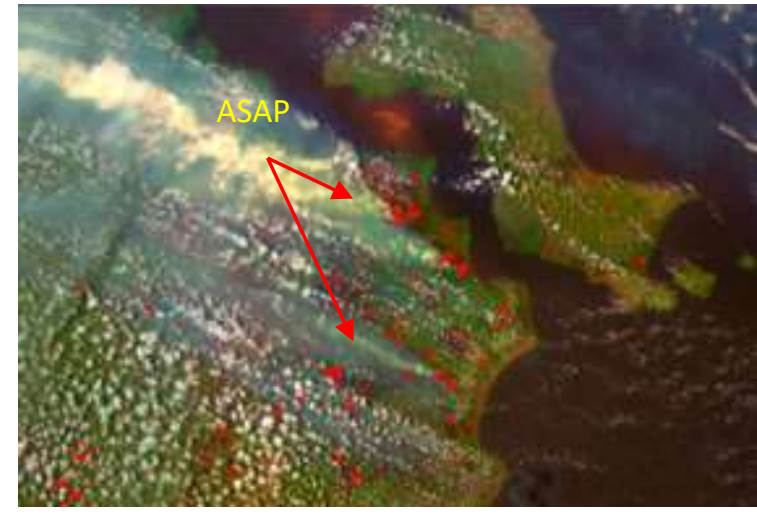

Gambar 1 Citra Komposit RGB 10-7-2 dari data VIIRS Tanggal 4 Oktober 2015.

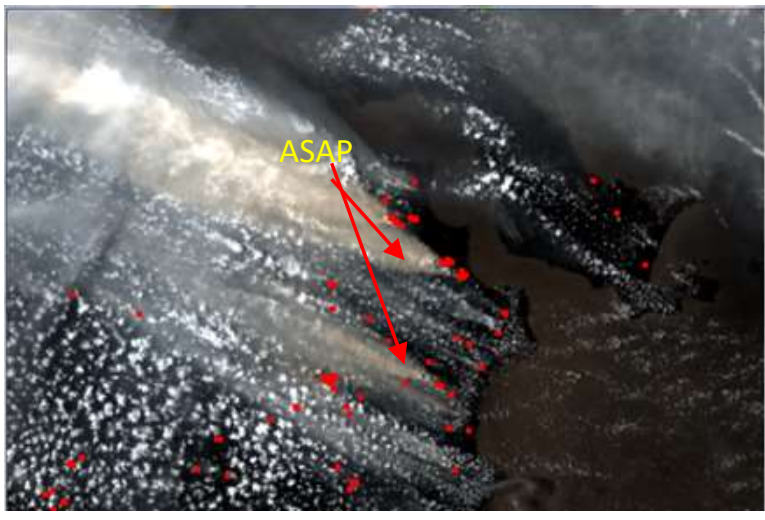

Gambar 2 Citra Komposit RGB 3-2-1 dari data VIIRS Tanggal 4 Oktober 2015.

Secara visual, pada citra komposit 10-7-2, asap menunjukkan warna putih kekuning-kuningan, sedangkan pada citra komposit 3-2-1 berwarna putih ke coklat-coklatan. Selanjutnya berdasarkan citra komposit tersebut dilakukan pengambilan training area untuk masing-masing obyek (asap dan non asap), dan dibuat klasifikasinya yang diuraikan pada penjelasan berikut. 


\section{Analisis Spektral Obyek Asap dan non Asap}

Analisis spektral obyek asap dan non asap didasarkan pada hasil klasifikasi obyek asap dan non asap (vegetasi, awan, dan air). Dari hasil ekstraksi nilai spektral masing-masing obyek asap dan non asap pada masing-masing kanal diperoleh pola spektral obyek asap dan non asap. Gambar 3 merupakan contoh beberapa training area dari obyek asap dan non asap (vegetasi, awan dan air).

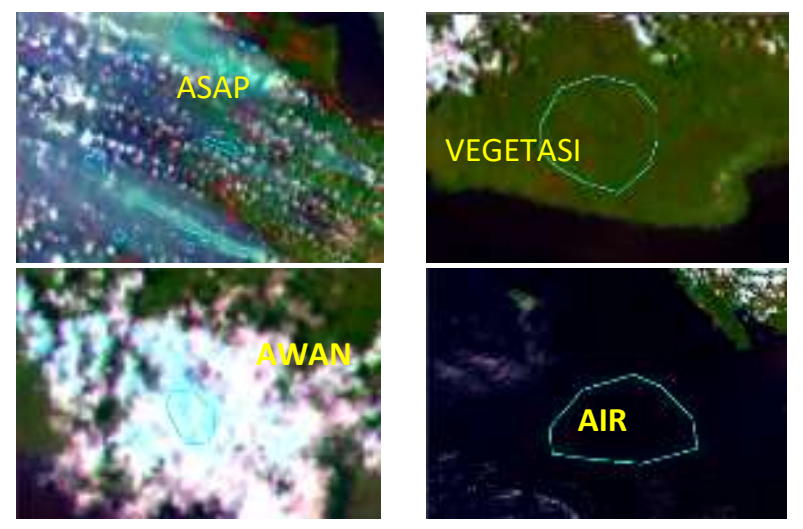

Gambar 3 Contoh traning sampel asap, vegetasi, awan, air.

Selanjutnya, selain ekstraksi nilai reflektansi obyek asap dan non asap diekstraksi pula nilai $B T$. Ekstraksi nilai reflektansi dan nilai $B T$ dilakukan untuk 11 tipe training area, yakni: kelas asap tebal di atas daratan (asapd_tb), asap tipis di atas daratan (asapd_tps), asap tipis di atas lautan (asapl_tps), awan tebal di atas daratan (awand_tb), awan tipis di atas daratan (awand_tps), awan tebal di atas lautan (awanl_tb), awan tipis di atas lautan (awanl_tps), air laut, vegetasi, asap tebal di atas daratan bercampur awan tebal (asapd_tb_awantb), dan asap tipis di atas daratan bercampur awan tebal (asapd_tps_awantb). Pola reflektansi asap dan non asap pada masing-masing kanal VIIRS yang diperoleh ditunjukkan pada Gambar 4, sedangkan pola $B T$ ditunjukkan pada Gambar 5. Penelitian ini merupakan kelanjutan dari penelitian yang dilakukan oleh Zubaidah et al. (2017). Dari hasil penelitian awal yang dilakukan oleh Zubaidah et al. (2017) tersebut telah ditunjukkan bahwa pola spektral reflektansi dan $B T$ asap kebakaran hutan/lahan dari data Soumi NPP-VIIRS dapat digunakan lebih lanjut untuk pengembangan model deteksi asap.

Berdasarkan pola reflektansi pada Gambar 4 dan Gambar 5, secara umum menunjukkan bahwa pada kanal-kanal visibel $\left(\mathrm{M}_{1}\right.$ hingga $\left.\mathrm{M}_{5}\right)$ nilai reflektansi obyek asap lebih rendah dari obyek awan tebal baik di darat maupun di laut, namun lebih tinggi dari nilai reflektansi vegetasi dan air. Sementara itu, nilai reflektansi awan tipis dan asap tipis baik di darat maupun di laut memiliki nilai reflektansi yang tumpang tindih, berarti kenampakan secara visual antara asap tipis dan awan tipis sulit dibedakan. Menurut Gao et al. (2007), sulit membedakan antara asap kebakaran (smoke plume) dengan awan. Hal ini dikarenakan keduanya mempunyai karakteristik (reflektivitas tinggi) yang relatif sama. Akan tetapi, awan mempunyai $B T$ yang sangat rendah pada kanal-kanal inframerah gelombang panjang. Selain itu, asap dan awan pada atmosfir bawah mempunyai sifat yang mirip, sehingga akan terdapat kesalahan dalam klasifikasi.

Nilai reflektansi kanal $6\left(\mathrm{M}_{6}\right)$ dan $9\left(\mathrm{M}_{9}\right)$ tidak digunakan dalam analisis ini. Hal ini dikarenakan nilai reflektansi semua obyek; baik asap dan non asap, terpusat pada nilai yang relatif tidak berbeda. Akan tetapi jika dilihat dari pola $B T$ asap tipis memiliki nilai $B T$ yang lebih tinggi dibandingkan dengan awan tipis. Selanjutnya, berdasarkan pola reflektansi dan $B T$ beberapa obyek tersebut, maka kemampuan masing-masing kanal dapat dikaji lebih lanjut untuk analisis dan pengembangan model/algoritma deteksi asap. 


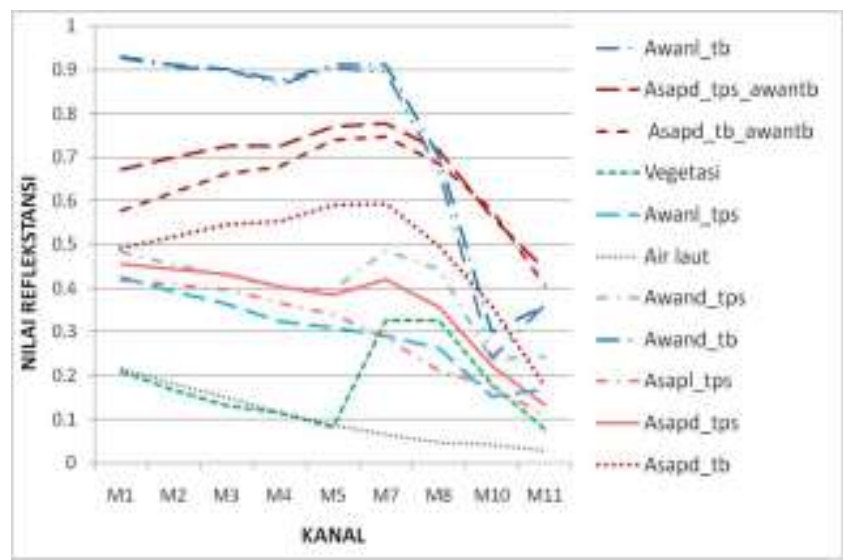

Gambar 4 Pola Reflektansi obyek asap (tipis, tebal), dan non asap.

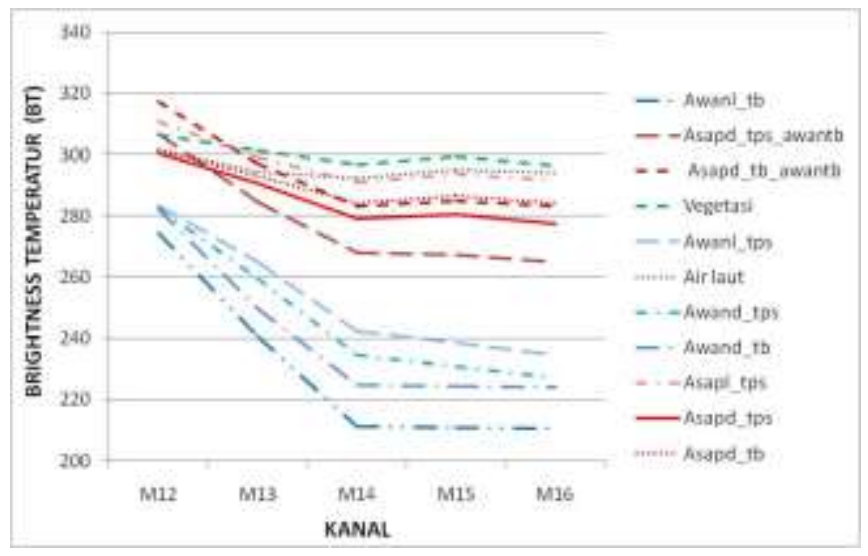

Gambar 5 Pola BT obyek asap (tipis, tebal), dan non asap.

\section{Perhitungan Normalized Distance (D) data VIIRS tanggal 4 Oktober 2015}

Normalized distance digunakan untuk menganalisis kemampuan masing-masing kanal dari variasi antara dua kelas obyek, misal obyek asap dan non asap. Nilai D dari data VIIRS ini dihitung berdasarkan formula (1) di atas sehingga diperoleh nilai D untuk reflektansi (Tabel 2) dan nilai D untuk BT (Tabel 3), kolom kanal maks adalah nilai kanal yang maksimum pada nilai D masing-masing untuk nilai kanal reflektansi (Tabel 2) dan kanal BT (Tabel 3). Pada Tabel 2 dan 3 yang dimaksud dengan kanal maks adalah kanal yang mempunyai nilai maksimum reflektansi dan BT paling tinggi dibandingkan kanal-kanal yang digunakan dalam ekstraksi nilai reflektansi dan BT pada setiap obyek.

Berdasarkan Tabel 2, pasangan obyek asap tebal di darat (Asapd_tb) dengan awan tebal di darat (awand_tb) memiliki nilai $\mathrm{D}$ tertinggi pada kanal $\mathrm{M}_{1}$, sedangkan dengan obyek vegetasi pada kanal $\mathrm{M}_{4}$ dan dengan obyek air pada kanal $\mathrm{M}_{3}$.

Obyek asap tipis dengan obyek awan tipis baik di darat maupun di laut (asapd_tps dan asapl_tps) dengan obyek awan tipis baik di darat maupun di laut memiliki nilai $\mathrm{D}$ tertinggi pada kanal $\mathrm{M}_{11}$, dengan obyek vegetasi pada kanal $\mathbf{M}_{4}$ dan dengan obyek air pada kanal $\mathbf{M}_{7}$. Sementara untuk obyek asap bercampur awan tebal (asapd_tb_awan) dengan awan tebal (awand_tb) memiliki nilai D tertinggi pada kanal $\mathrm{M}_{1}$.

Tabel 2 Normalized Distance (D) untuk nilai Reflektansi.

\begin{tabular}{lllllllllll}
\hline \multicolumn{1}{c}{ Nilai D untuk Reflekktansi } & M1 & M2 & \multicolumn{1}{c}{ M3 } & M4 & M5 & M7 & M8 & M10 & M11 & Kanal Maks. \\
\hline Asapd_tb_vs_Awand_tb & 3,085 & 2,699 & 2,288 & 1,970 & 1,675 & 1,670 & 1,262 & 0,310 & 1,937 & M1 \\
Asapd_tb_vs_Vegetasi & 4,672 & 6,623 & 8,118 & 8,283 & 7,500 & 2,031 & 1,382 & 2,282 & 1,571 & M4 \\
Asapd_tb_vs_Air & 6,732 & 9,054 & 10,368 & 9,932 & 7,652 & 6,782 & 5,161 & 3,729 & 2,292 & M3 \\
Asap1_tps_vs_Awanl_tps & 0,041 & 0,091 & 0,164 & 0,199 & 0,131 & 0,022 & 0,315 & 0,333 & 0,968 & M11 \\
Asapd_tps_vs_Awand_tps & 0,264 & 0,078 & 0,016 & 0,024 & 0,085 & 0,571 & 0,907 & 0,298 & 1,236 & M11 \\
Asapd_tps_vs_Vegetasi & 2,872 & 3,564 & 4,068 & 4,085 & 3,848 & 0,719 & 0,290 & 0,875 & 0,838 & M4 \\
Asapd_tps_vs_Air & 3,606 & 4,226 & 4,607 & 4,645 & 3,883 & 4,733 & 4,366 & 3,291 & 1,529 & M7 \\
Asapd_tb_Awan_vs_Awand_tb & 1,792 & 1,448 & 1,165 & 0,961 & 0,778 & 0,760 & 0,088 & 1,181 & 0,305 & M1 \\
Asapd_tps_Awan_vs_Awand_tb & 1,704 & 1,327 & 1,054 & 0,861 & 0,716 & 0,691 & 0,082 & 1,238 & 0,726 & M1 \\
\hline
\end{tabular}


Tabel 3 Normalized Distance (D) untuk nilai $B T$.

\begin{tabular}{|c|c|c|c|c|c|c|}
\hline Nilai D untuk Reflektansi & M12 & M13 & M14 & M15 & M16 & $\begin{array}{l}\text { Kanal } \\
\text { Maks }\end{array}$ \\
\hline Asapd_tb_VS_Awand_tb & 1,01 & 1,748 & 1,804 & 1,766 & 1,687 & M14 \\
\hline Asapd_tb_VS_Vegetasi & 0,705 & 0,957 & 1,107 & 1,037 & 0,954 & M14 \\
\hline Asapd_tb_VS_Air & 0,023 & 0,223 & 0,954 & 0,863 & 0,948 & M14 \\
\hline Asap1_tps_VS_Awan1_tps & 1,731 & 2,618 & 3,933 & 4,404 & 4,708 & M16 \\
\hline Asapd_tps_VS_Awand-tps & 1,172 & 1,294 & 1,436 & 1,49 & 1,511 & M16 \\
\hline Asapd_tps_VS_Vegetasi & 0,489 & 0,575 & 0,672 & 0,663 & 0,651 & M14 \\
\hline Asapd_tps_VS_Air & 0,09 & 0,227 & 0,567 & 0,562 & 0,622 & M16 \\
\hline Asapd_tb_Awan_VS_Awand_tb & 1,623 & 1,71 & 2,061 & 2,028 & 1,976 & M14 \\
\hline Asapd_tps_Awan_VS_Awand_tb & 1,073 & 1,376 & 1,354 & 1,279 & 1,201 & M13 \\
\hline
\end{tabular}

Nilai D untuk $B T$, pada obyek asap tebal di darat (asapd_tb) baik dengan awan tebal di darat (awand_tb) maupun dengan vegetasi dan air semua memiliki nilai $\mathrm{D}$ tertinggi pada kanal $\mathrm{M}_{14}$, sedangkan obyek asap tipis baik di darat maupun di laut (asapd_tps dan asapl_tps) dengan obyek awan tipis baik di darat maupun di laut (awand_tps dan awanl_tps) memiliki nilai D tertinggi pada kanal $\mathbf{M}_{16}$, dengan obyek vegetasi pada kanal $\mathrm{M}_{14}$ dan dengan obyek air pada kanal $\mathbf{M}_{16}$. Sementara obyek asap tebal bercampur awan di darat (asapd_tb_awan) dengan awan darat tebal (awand_tb) memiliki nilai D tertinggi pada $\mathrm{M}_{14}$, dan obyek asap tipis bercampur awan (asapd_tps_awan) dengan awan tebal di darat (awand_tb) terjadi pada kanal $\mathrm{M}_{13}$.

\section{Deteksi asap kebakaran hutan dan lahan}

\section{Deteksi asap dengan Multi-Threshold}

Deteksi asap kebakaran hutan dan lahan menggunakan multi- threshold dengan mengambil threshold $(\mu \pm 2 \sigma)$, dimana $\mu$ adalah nilai rata-rata obyek dan $\sigma$ merupakan standar deviasi obyek. Tabel 4 merupakan nilai threshold untuk reflektansi. Nilai threshold reflektansi ini dihitung berdasarkan nilai Normalized Distance (D) reflektansi tertinggi pada Tabel 2. Demikian juga untuk perhitungan nilai threshold BT pada Tabel 5, yang dihitung perdasarkan nilai $\mathrm{D}$ untuk $B T$ pada Tabel 3 dengan nilai $\mathrm{D}$ tertinggi.

Berdasarkan nilai threshold pada Table 4 dan Tabel 5 diperoleh 9 pasang variasi kanal yang dapat digunakan dalam penyusunan model dengan menggunakan kanal reflektansi dan kanal $B T$ seperti ditunjukkan pada Tabel 6.

Tabel 4 Nilai threshold untuk reflektansi.

\begin{tabular}{clccccc}
\hline No. & \multicolumn{1}{c}{ Kelas } & Kanal & $\mu$ & $\sigma$ & $\mu-2 \sigma$ & $\mu+2 \sigma$ \\
\hline 1 & Asapd_tb_vs_Awand_tb & M1 & 0,493 & 0,025 & 0,443 & 0,543 \\
2 & Asapd_tb_vs_Vegetasi & M4 & 0,553 & 0,040 & 0,473 & 0,633 \\
3 & Asapd_tb_vs_Air & M3 & 0,545 & 0,033 & 0,479 & 0,611 \\
4 & Asap1_tps_vs_Awanl_tps & M11 & 0,134 & 0,053 & 0,028 & 0,240 \\
5 & Asapd_tps_vs_Awand_tps & M11 & 0,110 & 0,017 & 0,076 & 0,144 \\
6 & Asapd_tps_vs_Vegetasi & M4 & 0,404 & 0,058 & 0,288 & 0,520 \\
7 & Asapd_tps_vs_Air & M7 & 0,419 & 0,060 & 0,299 & 0,539 \\
8 & Asapd_tb_berawan_vs_Awand_tb & M1 & 0,578 & 0,080 & 0,418 & 0,738 \\
9 & Asapd_tps_berawan_vs_Awand_tb & M1 & 0,672 & 0,035 & 0,602 & 0,742 \\
\hline
\end{tabular}


Tabel 5 Nilai threshold untuk BT.

\begin{tabular}{llccccc}
\hline No. & \multicolumn{1}{c}{ Kelas } & Kanal & $\mu$ & $\boldsymbol{\sigma}$ & $\mu-2 \sigma$ & $\mu+2 \sigma$ \\
\hline 1 & Asapd_tb_vs_Awand_tb & M14 & 284,34 & 7,95 & 268 & 300 \\
2 & Asapd_tb_vs_Vegetasi & $\mathrm{M} 14$ & 284,34 & 7,95 & 268 & 300 \\
3 & Asapd_tb_vs_Air & $\mathrm{M} 14$ & 284,34 & 7,95 & 268 & 300 \\
4 & Asap1_tps_vs_Awanl_tps & $\mathrm{M} 16$ & 291,81 & 2,75 & 286 & 297 \\
5 & Asapd_tps_vs_Awand_tps & $\mathrm{M} 16$ & 277,56 & 26,03 & 225 & 330 \\
6 & Asapd_tps_vs_Vegetasi & $\mathrm{M} 14$ & 279,24 & 22,73 & 234 & 325 \\
7 & Asapd_tps_vs_Air & $\mathrm{M} 16$ & 277,56 & 26,03 & 225 & 330 \\
8 & Asapd_tb_berawan_vs_Awand_tb & $\mathrm{M} 14$ & 283,32 & 3,34 & 277 & 290 \\
9 & Asapd_tps_berawan_vs_Awrand_tb & $\mathrm{M} 13$ & 267,95 & 6,79 & 254 & 282 \\
\hline
\end{tabular}

Tabel 6 Model dari Pasangan variasi kanal Reflektansi dan kanal BT.

\begin{tabular}{|c|c|c|}
\hline No. & Kelas & $\begin{array}{l}\text { MODEL } \\
(\mu \pm 2 \sigma)\end{array}$ \\
\hline 1 & Asapd_tb_vs_Awand_tb & $\begin{array}{c}0.443<M 1 \leq 0.543 \\
0.268<M 14 \leq 0.300\end{array}$ \\
\hline 2 & Asapd_tb_vs_Vegetasi & $\begin{array}{c}0.473<M 4 \leq 0.633 \\
0.268<M 14 \leq 0.300\end{array}$ \\
\hline 3 & Asapd_tb_vs_Air & $\begin{array}{c}0.479<M 3 \leq 0.611 \\
0.268<M 14 \leq 0.300\end{array}$ \\
\hline 4 & Asapl_tps_vs_Awanl_tps & $\begin{array}{l}0.028<M 11 \leq 0.024 \\
0.268<M 16 \leq 0.297\end{array}$ \\
\hline 5 & Asapd_tps_vs_Awand_tps & $\begin{array}{l}0.076<M 11 \leq 0.144 \\
0.225<M 16 \leq 0.330\end{array}$ \\
\hline 6 & Asapd_tps_vs_Vegetasi & $\begin{array}{c}0.288<M 450.52 \\
0.234<M 1450.325\end{array}$ \\
\hline 7 & Asapd_tps_vs_Air & $\begin{array}{c}0.299<M 7 \leq 0.539 \\
0.225<M 16 \leq 0.330\end{array}$ \\
\hline 8 & Asapd_tb_berawan_vs_Awand_tb & $\begin{array}{c}0.418<M 1 \leq 0.738 \\
0.277<M 1450.290\end{array}$ \\
\hline 9 & Asapd_tps_berawan_vs_Awand_tb & $\begin{array}{c}0.602<M 1 \leq 0.742 \\
0.254<M 1350.282\end{array}$ \\
\hline
\end{tabular}

Dari 9 (Sembilan) model pasangan variasi kanal (reflektansi, BT), dipilih beberapa model yang cukup merepresentasikan distribusi asap kebakaran hutan dan lahan, yaitu model nomer 1, 2, 3, 4, dan model 7. Hal ini dikarenakan model-model yang lain model $(5,6,8$, dan 9) sudah tercakup di dalamnya.

Hasil penerapan berbagai model deteksi asap kebakaran hutan dan lahan (model 1, 2, 3, 4, dan 7) ditunjukkan pada Tabel 7. Selanjutnya dalam proses penyusunan model dilakukan penghalusan citra menggunakan teknik filtering citra berdasarkan nilai statistik Median 3 x 3 (Anonim, 2017).

Pada Tabel 7 terlihat bahwa model 2 dengan menggunakan kanal $\mathrm{M}_{4} \& \mathrm{M}_{14}$ dan model 3 dengan menggunakan kanal $\mathrm{M}_{3} \& \mathrm{M}_{14}$ mendekati sebaran asap yang sebenarnya, namun hasilnya masih kurang bagus. Oleh karena pada hasil kedua model (model 2 dan 3) tampak untuk kondisi sebaran corong asap (plume smoke) di sekitar sumber kebakaran (lingkaran kuning) tidak sepenuhnya terkelaskan sebagai asap. Sementara itu, plume smoke dari model 4 dan 7 bahkan tidak dapat teridentifikasi. Li et al. (2001) yang menggunakan data kanal 1, 2 dan 4 NOAA/AVHRR dengan algoritma jaringan syaraf (neural network) mendapatkan kondisi yang sama, yakni tidak mampu mengidentifikasi piksel-piksel asap tipis yang tersebar mengikuti arah angin (smoke plume). 
Tabel 7 Model deteksi asap kebakaran hutan/ lahan menggunakan multi-threshold $(\mu \pm 2 \sigma)$.

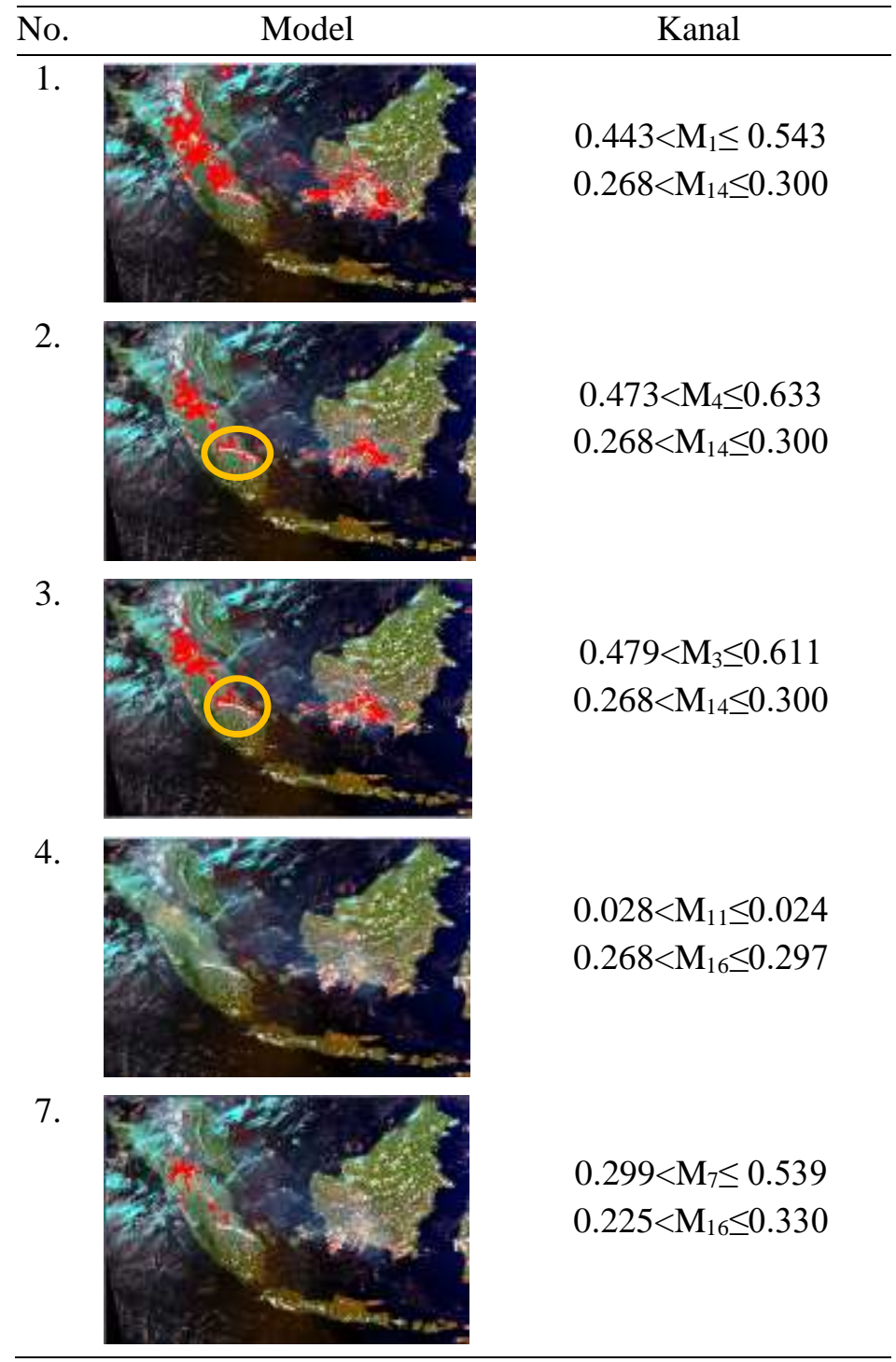

Oleh karena itu, tahap berikutnya dilakukan modifikasi nilai thresholdnya pada kedua model tersebut dengan cara trail and error. Gambar 6(A) merupakan hasil modifikasi trail and error dari model 2 deteksi asap kebakaran hutan dan lahan dengan threshold $(\mu \pm 2 \sigma)$ dengan filter median kernel 3x3, sedangkan Gambar 6(B) merupakan hasil modifikasi trail and error dari model 3 dengan threshold $(\mu \pm 2 \sigma)$ dan filter median kernel $3 \times 3$. Filter ini digunakan untuk memperhalus suatu citra dan menghilangkan noise atau gangguan. Filter median kernel $3 \times 3$ merupakan suatu metode yang menitik beratkan pada nilai median atau nilai tengah dari jumlah total nilai keseluruhan pixel $3 \times 3$ yang ada di sekelilingnya.

Selanjutnya berdasarkan modifikasi kedua model tersebut, model untuk deteksi asap kebakaran hutan/lahan yang dipilih adalah model yang menggunakan nilai threshold dari reflektansi kanal M4 dan nilai threshold dari $B T$ kanal M14 dengan formula atau model sebagai berikut: Nilai reflektansi antara $0.325<\mathrm{M}_{4} \leq 0.611$ dan nilai BT berkisar $0.268<\mathrm{M}_{14} \leq 0.300$.

Namun demikian, hasil modifikasi pada model 2 dan 3 juga belum mendapatkan hasil yang maksimal, yakni sebaran asap yang mengikuti arah angin (smoke plume) atau di sekitar sumber asap belum dapat teridentifikasi dengan baik.

Menurut Li et al. (2001) metode multi-threshold cukup efektif digunakan untuk deteksi asap, namun sangat sulit untuk mendapatkan threshold yang tetap untuk citra pada wilayah dan kondisi musim yang berbeda. 


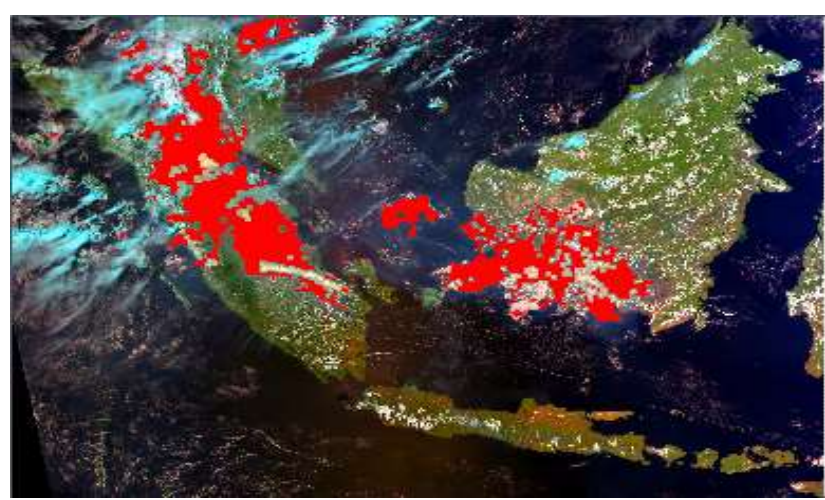

(A) Modifikasi Model 2 dengan median kernel 3 x 3

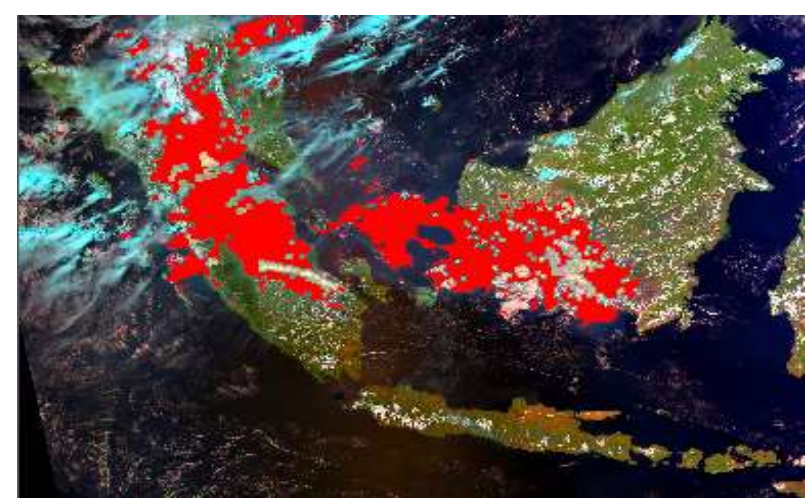

(B) Modifikasi Model 3 dengan median kernel 3 x 3

Gambar 6 Model kebakaran hutan dan lahan hasil modifikasi nilai threshold $(\mu \pm 2 \sigma)$

dengan filter median kernel $3 \times 3$.

\section{Deteksi Asap dengan Modifikasi Model Li et al. (2015)}

Data yang digunakan adalah data VIIRS tanggal yang sama seperti data pada penerapan model multithreshold, yakni Citra komposit VIIRS RGB 10-7-2 tanggal 4 oktober 2015 seperti yang ditunjukkan pada Gambar 7a. Gambar 7 menjelaskan tahapan langkah demi langkah penentuan threshold untuk deteksi asap kebakaran hutan/lahan. Persamaan 1 pada formula (3), yaitu: $0.4 \leq\left(\mathrm{M}_{1}-\mathrm{M}_{7}\right) /\left(\mathrm{M}_{1}+\mathrm{M}_{7}\right) \leq 0.85$ dengan kanal $\mathrm{M}_{1}$ adalah kanal visible (blue) dan $\mathrm{M}_{7}$ adalah kanal Inframerah dekat (NIR). Jika persamaan 1 diaplikasikan pada citra VIIRS tanggal 4 Oktober 2015, terlihat bahwa yang terklasifikasi hanya obyek air (Gambar 7b). Oleh karena itu, untuk selanjutnya persamaan 1 pada formulasi (3) tidak digunakan. Tahap selanjutnya dilakukan penerapan persamaan 2 pada formula (3) yaitu $\left(\mathrm{M}_{2}-\mathrm{M}_{11}\right) /\left(\mathrm{M}_{2}+\mathrm{M}_{11}\right) \geq 0.3$ dengan $\mathrm{M}_{2}$ masih merupakan kanal visibel (blue) dan $\mathrm{M}_{11}$ adalah kanal SWIR (Shortwave Infra Red). Hasil penerapan persamaan ini menunjukkan bahwa awan-awan tipis dan sebagian besar permukaan laut terklasifikasikan menjadi satu kelas, kecuali sebagian obyek Awan sangat tinggi dan obyek vegetasi yang tidak tertutup oleh awan (Gambar 7c).

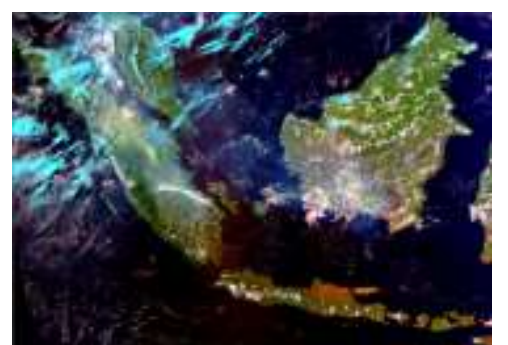

(a) Citra Komposit VIIRS RGB 10-7-2 tanggal 4 Oktober 2015

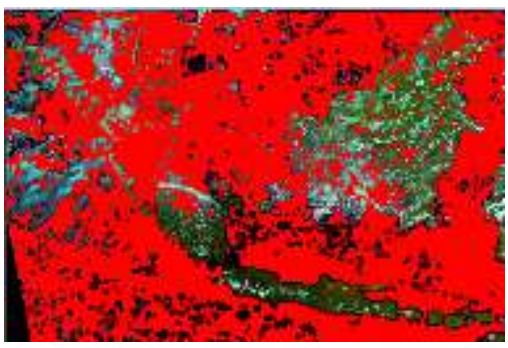

(c) $\left(\mathrm{M}_{1}-\mathrm{M}_{7}\right) /\left(\mathrm{M}_{1}+\mathrm{M}_{7}\right) \geq 0.3$ (2)

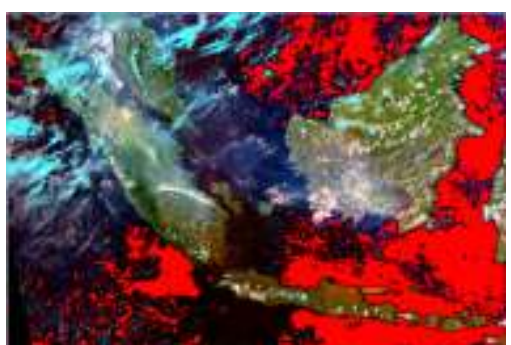

(b) $0.4 \leq\left(\mathrm{M}_{1}-\mathrm{M}_{7}\right) /\left(\mathrm{M}_{1}+\mathrm{M}_{7}\right) \leq 0.85$

(1)

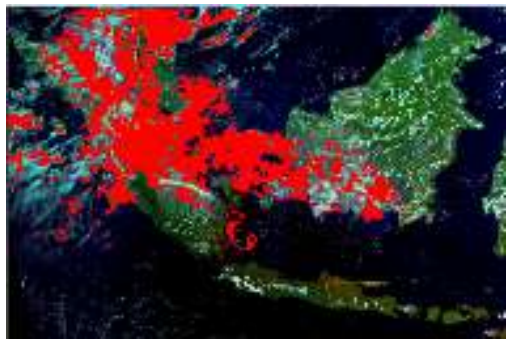

(d) $\left(\mathrm{M}_{2}-\mathrm{M}_{11}\right) /\left(\mathrm{M}_{2}+\mathrm{M}_{11}\right) \geq 0.3$ (2)

dan $\left(\mathrm{M}_{1}-\mathrm{M}_{3}\right) /\left(\mathrm{M}_{1}+\mathrm{M}_{3}\right) \leq 0.09$ (3) 


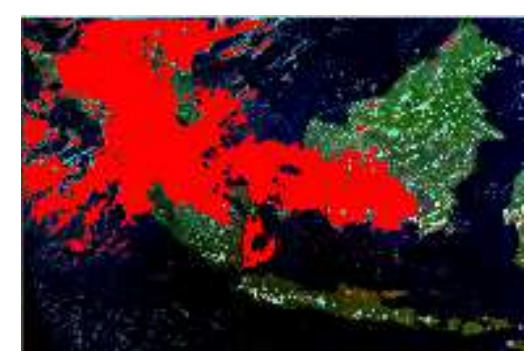

(e) $\left(\mathrm{M}_{2}-\mathrm{M}_{11}\right) /\left(\mathrm{M}_{2}+\mathrm{M}_{11}\right) \geq 0.1$ (2) dan $\left(\mathrm{M}_{1}-\mathrm{M}_{3}\right) /\left(\mathrm{M}_{1}+\mathrm{M}_{3}\right) \leq 0.09$

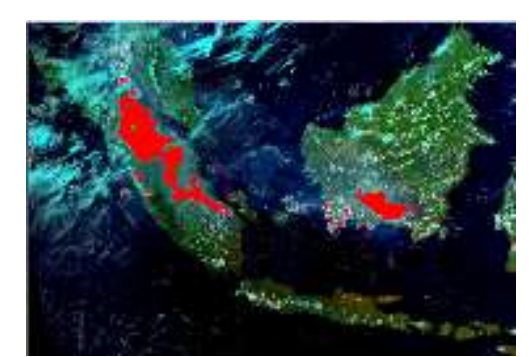

(g) $\left(\mathrm{M}_{2}-\mathrm{M}_{11}\right) /\left(\mathrm{M}_{2}+\mathrm{M}_{11}\right) \geq 0.1$ (2) dan $\left(\mathrm{M}_{1}-\mathrm{M}_{3}\right) /\left(\mathrm{M}_{1}+\mathrm{M}_{3}\right) \leq 0.02$ (3) dan $\mathrm{M}_{1} \geq 0.09(4)$

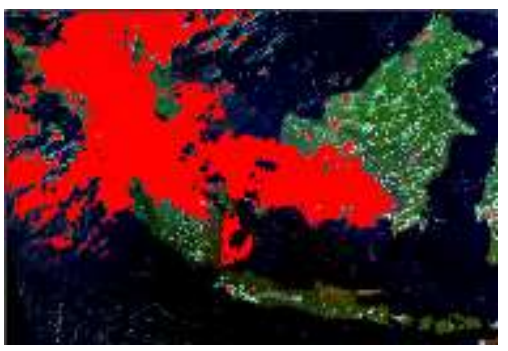

(f) $\left(\mathrm{M}_{2}-\mathrm{M}_{11}\right) /\left(\mathrm{M}_{2}+\mathrm{M}_{11}\right) \geq 0.1$ (2) dan $\left(\mathrm{M}_{1}-\mathrm{M}_{3}\right) /\left(\mathrm{M}_{1}+\mathrm{M}_{3}\right) \leq 0.09$ (3) dan $\mathrm{M}_{1} \geq 0.09$ (4)

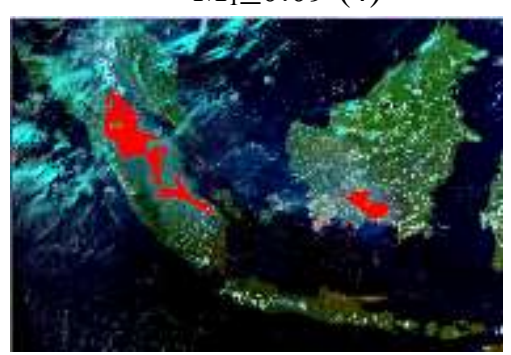

(h) $\left(\mathrm{M}_{2}-\mathrm{M}_{11}\right) /\left(\mathrm{M}_{2}+\mathrm{M}_{11}\right) \geq 0.1$ dan

$\left(\mathrm{M}_{1}-\mathrm{M}_{3}\right) /\left(\mathrm{M}_{1}+\mathrm{M}_{3}\right) \leq 0.015$ dan $\mathrm{M}_{1} \geq 0.09$

Gambar 7 Langkah-langkah penentuan threshold untuk deteksi asap kebakaran hutan dan lahan menggunakan modifikasi Li et al. (2015).

Guna mengeliminasi obyek air dilakukan penerapan persamaan 3 yaitu: $\left(\mathrm{M}_{2}-\mathrm{M}_{11}\right) /\left(\mathrm{M}_{2}+\mathrm{M}_{11}\right) \geq 0.3$ dan $\left(\mathrm{M}_{1}-\mathrm{M}_{3}\right) /\left(\mathrm{M}_{1}+\mathrm{M}_{3}\right) \leq 0.09$ seperti pada Gambar $7 \mathrm{~d}$, namun sebagian obyek asap bercampur awan tinggi menjadi tereliminasi. Oleh karena itu, obyek tersebut dikembalikan dengan cara mengganti nilai threshold pada persamaan 2, yaitu 0.3 diubah menjadi $\left(\mathrm{M}_{2}-\mathrm{M}_{11}\right) /\left(\mathrm{M}_{2}+\mathrm{M}_{11}\right) \geq 0.1$ (Gambar 7e), sehingga obyek yang tersisa adalah obyek asap, awan, dan asap bercampur awan.

Langkah berikutnya untuk mengurangi obyek awan ditambahkan persamaan 4 yaitu $\mathrm{M}_{1} \geq 0.09$, namun hasilnya tidak merubah obyek-obyek yang ada (Gambar 8f). Selanjutnya dengan menggunakan teknik trail and error nilai threshold pada persamaan 3 yaitu $\left(\mathrm{M}_{1}-\mathrm{M}_{3}\right) /\left(\mathrm{M}_{1}+\mathrm{M}_{3}\right) \leq 0.09$ dimodifikasi dengan tujuan untuk mengurangi obyek awan. Jika nilai threshold diganti 0.02 masih terdeteksi adanya awan (Gambar $7 \mathrm{~g}$ ), tetapi jika nilai threshold diganti kurang dari 0.15 ada sebagian obyek asap yang hilang (Gambar $7 \mathrm{~h}$ ), sehingga persamaan 3 dimodifikasi menjadi $\left(\mathrm{M}_{1}-\mathrm{M}_{3}\right) /\left(\mathrm{M}_{1}+\mathrm{M}_{3}\right) \leq 0.015$. Hasil terakhir model deteksi asap kebakaran hutan dan lahan menggunakan modifikasi metode Li et al. (2015) adalah seperti ditunjukkan pada formula berikut:

$$
\begin{gathered}
\left(\mathrm{M}_{2}-\mathrm{M}_{11}\right) /\left(\mathrm{M}_{2}+\mathrm{M}_{11}\right) \geq 0.1 \quad \text { dan } \\
\left(\mathrm{M}_{1}-\mathrm{M}_{3}\right) /\left(\mathrm{M}_{1}+\mathrm{M}_{3}\right) \leq 0.015 \text { dan } \mathrm{M}_{1} \geq 0.09
\end{gathered}
$$

\section{Validasi Model dan Pengujian Akurasi}

Model deteksi asap kebakaran hutan dan lahan yang diperoleh menggunakan metode multi-threshold dan modifikasi metode Li et al. (2015) selanjutnya diterapkan terhadap data VIIRS lain yang terindikasi adanya asap, yakni data tanggal 10, 11, 15, dan 25 Oktober 2015. Gambar 8 sampai dengan Gambar 11 merupakan hasil penerapan model yang diperoleh terhadap data tanggal 10, 11, 15, dan 25 Oktober 2015.

Hasil penerapan model multithreshod menunjukkan bahwa sebagian besar obyek asap tebal dan asap tipis terklasifikasi menjadi kelas yang sama, sehingga luasan area yang teridentifikasi sebagai obyek asap menjadi lebih luas. Sementara itu, penerapan hasil modifikasi metode Li et al. (2015) menghasilkan asap tebal dan sebagian kecil asap tipis saja yang teridentifikasi sebagai obyek asap dan luasan yang dihasilkan tidak terlalu luas. 
Selanjutnya uji akurasi masing-masing model terhadap data tanggal 25 Oktober 2015 dilakukan dengan menghitung nilai Commision error dan Ommision error. Nilai Commision error dan Ommision error dihitung dengan cara membandingkan antara luas obyek asap yang teridentifikasi berdasarkan model Multi-Threshold dan hasil modifikasi metode Li et al. (2015) dengan hasil delineasi obyek asap secara visual.

Hasil uji akurasi menunjukkan bahwa dengan menggunakan model Multi-Threshold diperoleh nilai akurasi rata-rata sebesar $82.2 \%$ dengan Commision error sebesar $9.8 \%$ dan Ommision error $10 \%$. Sementara itu, berdasarkan Modifikasi metode Li et al. (2015) diperoleh nilai akurasi rata-rata sebesar $72.3 \%$ dengan Commision error sebesar $0.3 \%$ dan Ommision error $27.4 \%$. Hasil ini menunjukkan bahwa nilai akurasi model multi-threshold lebih tinggi dibandingkan dengan hasil modifikasi model Li et al. (2015).
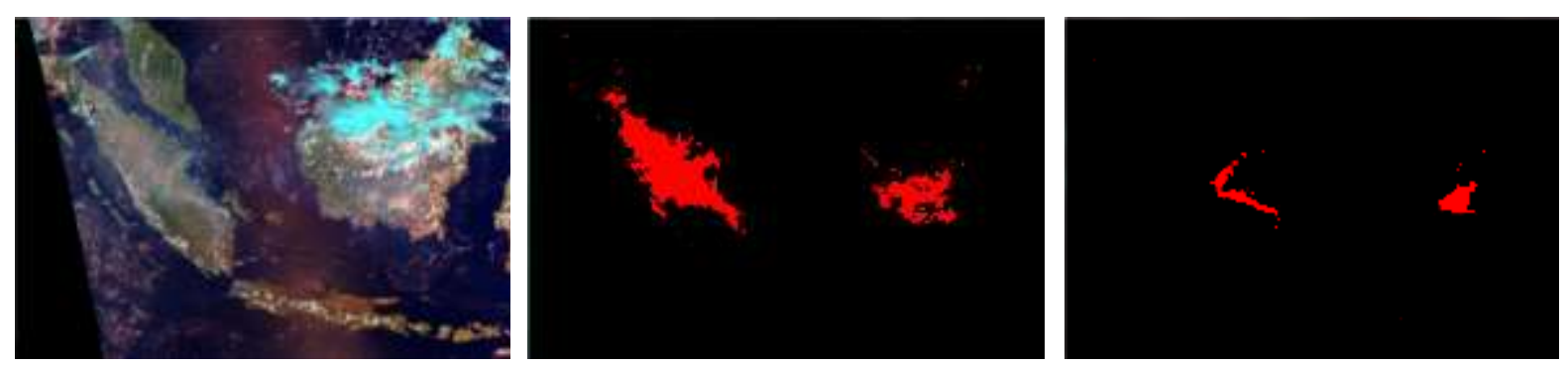

Gambar 8(A) Citra VIIRS, RGB 10-7-2 Tanggal 10 Oktober 2015, (B) Hasil Aplikasi model Multithreshold, (C) Hasil aplikasi model modifikasi Li et al. (2015).
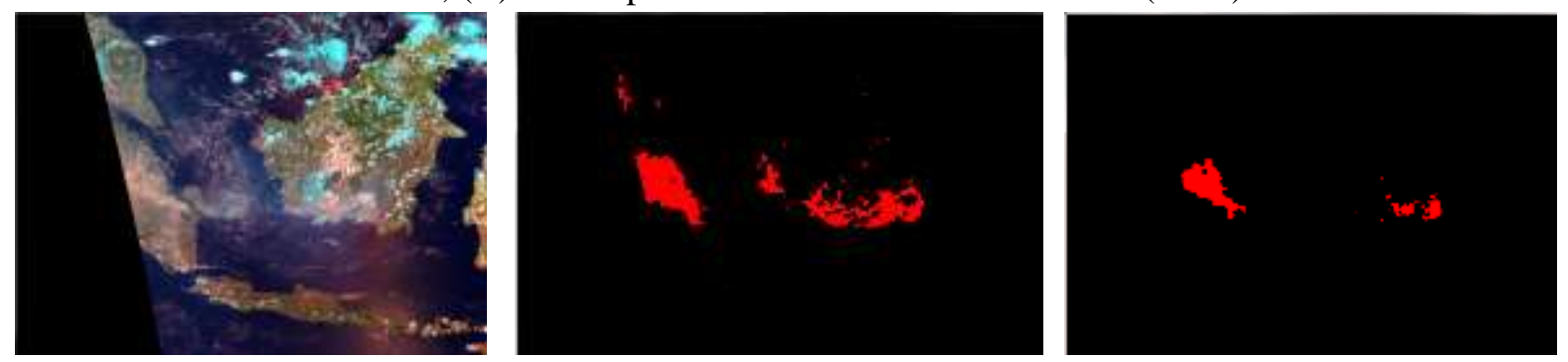

Gambar 8 (A) Citra VIIRS, RGB 10-7-2 Tanggal 11 Oktober 2015, (B) Hasil Aplikasi model Multithreshold, (C) Hasil aplikasi model modifikasi Li et al. (2015).
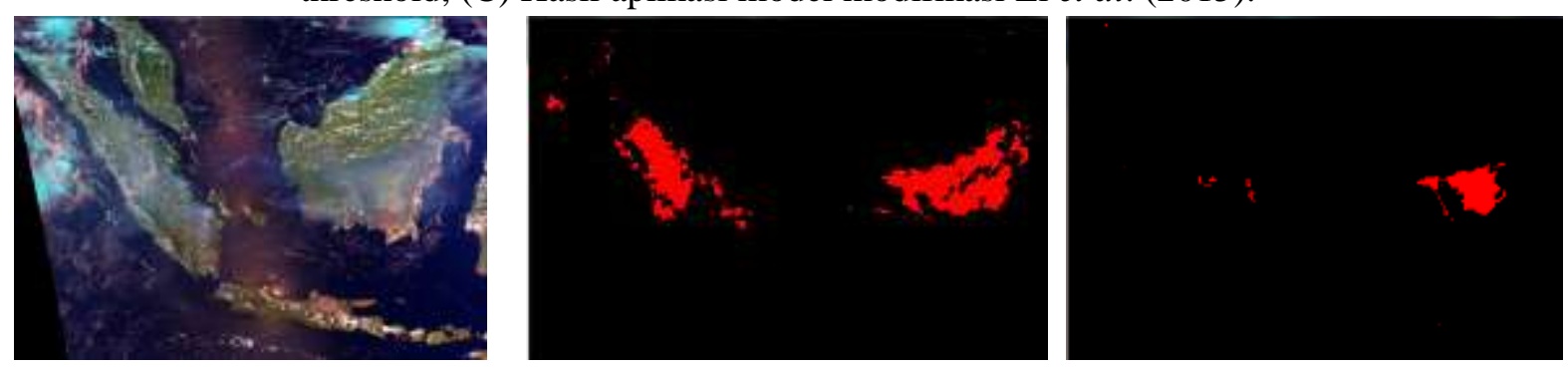

Gambar 9 (A) Citra VIIRS, RGB 10-7-2 Tanggal 15 Oktober 2015, (B) Hasil Aplikasi model Multithreshold, (C) Hasil aplikasi model modifikasi Li et al. (2015).
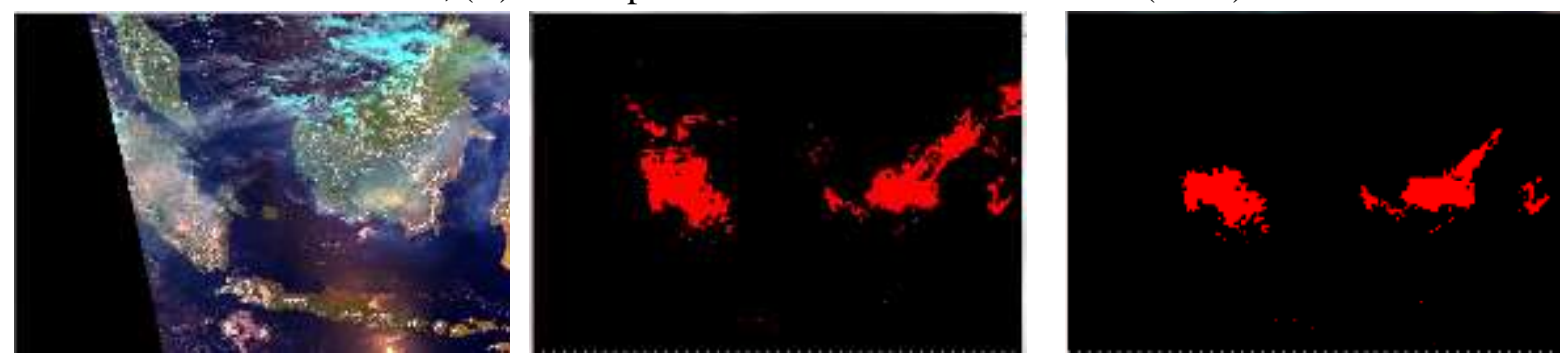

Gambar 10 (A) Citra VIIRS, RGB 10-7-2 Tanggal 25 Oktober 2015, (B) Hasil Aplikasi model Multi-threshold, (C) Hasil aplikasi model modifikasi Li et al. (2015). 
Pada model multi-threshold ini terjadi kesalahan deteksi hampir seimbang antara obyek asap terdeteksi menjadi non asap ataupun sebaliknya obyek non asap yang terdeteksi menjadi asap yaitu sebesar $10 \%$. Dalam hal ini, berarti pada model pengembangan modifikasi metode Li et al. (2015) masih banyak obyek asap yang tidak terdeteksi.

Menurut Li et al. (2015) sulit membedakan antara smoke plume dengan awan dikarenakan keduanya mempunyai karakteristik pantulan yang tinggi. Namun demikian, awan akan mempunyai BT yang sangat rendah pada kanal inframerah gelombang panjang (Gao et al. 2007). Su et al. (2017) menggunakan rasio antara kanal 2 dan 8 MODIS untuk mendeteksi asap, area asap dapat diidentifikasi jika rasio antara kanal 2 dan kanal 8 yang disebutnya Haze Indeks (HI) lebih besar dari 0.03. HI = (kanal $8-$ kanal 2$) /($ kanal $8+$ kanal 2), dengan kanal $2(405-420 \mu \mathrm{m})$ dan kanal $8(541-575 \mu \mathrm{m})$. Su et al. (2017) juga menyatakan bahwa asap mempunyai perbedaan $\mathrm{BT} \mathrm{T}_{31}$ dan $\mathrm{T}_{32}$ berkisar antara -0.1 hingga $1 \mathrm{~K}$ dengan puncaknya pada $0,1 \mathrm{~K}$. Hasil penelitian $\mathrm{Su}$ et al. (2017) selanjutnya mendapatkan bahwa asap dapat diidentifikasi dengan ketepatan tinggi jika tidak bercampur dengan awan. Namun, jika bercampur dengan awan atau wilayah asap tertutup oleh awan, maka sebagian besar sebaran asap tidak dapat teridentifikasi dengan baik.

\section{SIMPULAN}

Citra VIIRS cukup baik untuk deteksi sebaran asap kebakaran hutan/lahan dengan menggunakan model multi-threshold dan model modifikasi metode Li et al. (2015). Model multi-threshold menghasilkan akurasi lebih tinggi dibandingkan dengan modifikasi model Li et al. (2015). Model multi-threshold menghasilkan nilai akurasi rata-rata sebesar $82.2 \%$ dengan Commision error sebesar 9,8\% dan Ommision error 10\%, sedangkan model modifikasi metode Li et al. (2015) mempunyai nilai akurasi rata-rata sebesar $72.3 \%$ dengan Commision error sebesar $0.3 \%$ dan Ommision error $27.4 \%$.

Model multi-threshold dapat mendeteksi asap kebakaran hingga ke asap tipis, sedangkan pada model modifikasi metode Li et al. (2015) hanya mampu mendeteksi asap kebakaran tebal saja.

\section{UCAPAN TERIMA KASIH}

Makalah ini adalah bagian dari hasil riset kegiatan penelitian dan pengembangan model pemanfaatan data penginderaan jauh untuk deteksi asap kebakaran hutan dan lahan di Pusat Pemanfaatan Data Penginderaan Jauh-LAPAN pada tahun 2016. Terima kasih juga disampaikan kepada Bapak Andi Indradjad, S.Si., M. Eng (Leader) Tim INSINAS "Pengembangan Model Ekstraksi Parameter Geo-Bio-Fisik dari Data Penginderaan Jauh untuk Mendukung Peringatan Dini Kebakaran Hutan di Indonesia" yang telah memberikan dukungan pendanaan pada proses verifikasi di lapangan. Terima kasih kepada Dr. M. Rokhis Khomarudin yang telah memfasilitasi terselenggaranya penelitian ini. Terima kasih juga kepada Kepala Pusat Teknologi dan Data Penginderaan Jauh LAPAN yang telah menyediakan data VIIRS, serta Bapak Drs. Taufik Maulana MBA yang telah memberi masukan dan saran dalam penelitian ini.

\section{DAFTAR PUSTAKA}

Anonim. 2017. Menghaluskan-Citra-dengan-Filter-Statistik-Mean-Median-Max-Dan-Min. [Internet] [Diunduh 2017 Jul 31]. Tersedia pada: https://www.scribd.com/doc/57340992/.

Baum BA dan Trepte QZ. 1999. A Grouped Threshold Approach for Scene Identification in AVHRR Imagery. Journal of Atmospheric and Oceanic Technology. 16(1999): 793-800.

Chung YS dan Kim HS. 2008. Satellite Monitoring of Forest Fires and Associated Smoke Plumes Occuring in Korea. Air Qual Atmos Health. 1(1): 111-118.

Chung YS dan Le HV. 1984. Detection of Forest-fire Smoke Plumes by Satellite Imagery. Atmospheric Environment. 18(10): 2143-2151. 
Gao BC, Xiong XX, Li RR, Wang DY. 2007. Evaluation of the moderate resolution imaging spectrometer special 3.95-mu $\mathrm{m}$ fire channel and implications on fire channel selections for future satellite instruments. J. Appl. Remote Sens. 2007(1). doi:10.1117/1.2757715.

Gao RS, Schwarz JP, Kelly KK, Fahey DW, Watts LA, Thompson TL. 2007. A novel method for estimating light-scattering properties of soot aerosols using a modified single-particle soot photo-meter. Aerosol Sci. Technol. 41: 125.

Kaufman YJ, Remer LA. 1994. Detection of Forest Fire using MidIR Reflectance: and Application for Aerosols Study. IEEE Transactions on Geoscience and Remote Sensing. 32(3): 672-683.

Lee TE, Miller SD, Turk FJ, Schueler C, Julian R, Deyo S, Dills P, Wang S. 2006. The NPOESS VIIRS Day/Night Visible Sensor. Bulletin of The American Meteorological Society (BAMS). AMS100. [Journal Online] [Diunduh 2017 Agustus 3]. https://doi.org/10.1175/BAMS-87-2-191.

Li X, Song W, Lian L, Wei X. 2015. Forest Fire Smoke Detection Using Back-Propagation Neural Network Based on MODIS Data. Remote Sensing. 2015(7): 4473-4498.

Li XL, Wang J, Song WG, Ma J, Telesca L, Zhang YM. 2014. Automatic smoke detection in modis satellite data based on k-means clustering and fisher linear discrimination. Photogramm. Eng. Remote Sens. 2014 (80): 971-982.

Li ZQ, Khananian A, Fraser RH, Cihlar J. 2001. Automatic detection of fire smoke using artificial neural networks and threshold approaches applied to AVHRR imagery. Geoscience and Remote Sensing, IEEE Transactions. 39(9): 1859-1870. doi: 10.1109/36.951076.

NOAA. 2014. VIIRS Nightfire Nighttime Detection and Characterization of Combustion Sources. [Diakses 2014 November 14]. http: //www.ngdc.noaa.gov/eog/data/viirs fire/viirs html/download viirs fire.html.

Planologi. 2013. Komposit Band pada Citra Satelit \& Kegunaannya. [Internet] [Diakses 2017 Juli 18] http://malikaprianto10.blogspot.co.id/2013/04/komposit-band-pada-citra-satelit_24.html.

Prasasti I, Boer R, Ardiyansyah M, Buono A, Syaufina L, Vetrita Y. 2012. Analisis hubungan kode-kode SPBK (Sistem Peringkat Bahaya Kebakaran) dan hotspot dengan kebakaran hutan dan lahan di Kalimantan Tengah. Jurnal Pengelolaan Sumberdaya Alam dan Lingkungan. 2(2): 91-101.

Priyatna M, Khomarudin MR, Sukowati KAD. 2014. Spasial Pemantauan Kabut Asap (Haze) di Propinsi Riau dengan Menggunakan Google Earth. Bunga Rampai Pemanfaatan Data Penginderaan Jauh untuk Pemantauan, Deteksi dan Kajian Lingkungan. Crestpent Press.

Seaman C. 2013. Beginner's Guide to VIIRS Imagery Data. CIRA/Colorado State University. [Diakses 2017 November 23]. http://rammb.cira.colostate.edu/projects/npp/ Beginner_Guide_to_VIIRS_Imagery_Data.pdf.

Su Q, Sun L, Di M, Liu X, Yang Y. 2017. A method for the spectral analysis and identification of Fog, Haze and Dust storm using MODIS data. Atmos. Meas. Tech. Discuss., https://doi.org/10.5194/atm-2017-306. Manuscript under review for journal Atmos.Meas. Tech. Discussion started: 23 October 2017. () Author(s) 2017.CC BY 4.0 Licence.

Tacconi L. 2003. Kebakaran Hutan di Indonesia: Penyebab, Biaya dan Implikasi Kebijakan. Bogor: Center for International Forestry Research (CIFOR).

Tie X, Wu D, Brasseur G. 2009. Lung cancer mortality and exposure to atmsospheric aerosol particles in Guangzhou, China. Atmos. Environ. 43, 2375-2377.

Wang WT, Qu JJ, Hao XJ, Liu YQ, Sommers WT. 2007. An improved algorithm for small and cool fire detection using modis data: A preliminary study in the southeastern United States. Remote Sens. Environ. 2007 (108): 163-170.

Xie Y, Qu JJ, Xiong X, Hao X, Che N, Sommers W. 2007. Smoke Plume Detection in The Eastern United States using MODIS. International Journal of Remote Sensing. 28(10): 2007.

Zhao TX, Ackerman S, Guo W. 2010. Dust and Smoke Detection for Multi-Channel Imagers. Remote Sensing. 2010 (2): 2347-2368. doi: 10.3390/rs2102347.

Zubaidah A, Sulma S, Prasasti I. 2017. Analisis Pola Spektral Asap Kebakaran Hutan dan Lahan dari Data Soumi NPP-VIIRS. Bandung: Prosiding SNSA. 
Zubaidah A, Sulma S, Suwarsono, Vetrita Y, Priyatna M, Sukowati KAD. 2017. Akurasi Luas Areal Kebakaran Dari Data Landsat-8 OLI Wilayah Kalimantan. Majalah Ilmiah Globe. 19(1): 21-32.

Zubaidah A, Vetrita Y, Priyatna M. 2014. Pemanfaatan Data Penginderaan Jauh untuk Pemantauan Kebakaran Hutan/Lahan di Sumatera. Bunga Rampai Pemanfaatan Data Penginderaan Jauh untuk Pemantauan, Deteksi dan Kajian Lingkungan. Crestpent Press. 